\title{
CHANGES IN POSITION OF MAIZE CULTIVATION IN THE CROPPING PATTERN OF HIMACHAL PRADESH: 1990-91 TO 2014-15
}

\author{
Shivjeet Kaur ${ }^{1}$, Jaswinder Kaur ${ }^{2}$ and K. S Sohal ${ }^{3}$ \\ ${ }^{1}$ Assistant Professor, ${ }^{2}$ Research Scholar and ${ }^{3}$ Former Professor and Head, \\ Department of Geography, Punjabi University Patiala, Punjab, India \\ Email: jaswinderkk09@gmail.com
}

\section{How to cite this paper: \\ Kaur, Shivjeet, Kaur, Jaswinder and Sohal, K. S. (2021) Changes in Position of Maize Cultivation in the Cropping Pattern of Himachal Pradesh: 1990-91 to 2014-15, Journal of Global Resources, Vol. 07 (02) \\ DOI: \\ 10.46587/JGR.2021.v07i02.017}

Received: 15 Feb. 2021

Reviewed: 25 April 2021

Revised: 18 May 2021

Final Accepted: 09 June 2021

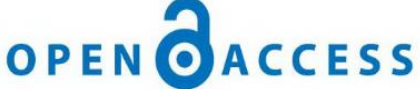

Freely available Online

\begin{abstract}
The study of ranking of crops is first step towards agricultural regionalization, because for demarcating crop regions, ranking of crops is the base. The major objective of this research paper is to findout the changes in spatial patterns of position of maize crop among the cropping pattern of Himachal Pradesh during 1990-91 to 2014-15. For achieving this aim, the study is of three folds: First part deals with spatial patterns of maize position in 1990-91 and 201415. Second part evaluates the changes in position of maize crop and identifies factors responsible for these changes. While conclusions are drawn and suggestions are made in third part. The study has found that the position of maize as second rank crop increases from east to west in 1990-91 as well as 2014-15, which is largely the result of geo-climatic conditions. It is also deduced that maize occupied first rank in 13 tehsils, second position in 49 tehsils, third position in 11 tehsils, fourth rank in 3 tehsils and above fourth rank in remaining tehsils in 1990-91. While number of tehsils is 10, $45,12,5$ and 13 as first, second, third, fourth and above fourth rank of maize in cropping pattern respectively in 201415. It is also deduced that 51 tehsils have experienced no change in their position, while 12 tehsils have noted negative change and 22 tehsils recorded positive change in their ranking order during study period. All these ups and downs in the ranking order of maize crop are largely the result of partly geo-climatic conditions and partly of socio-economic parameters. The present study is empirical in nature and is based on secondary sources of data which is collected personally from alltehsils headquarters of Himachal Pradesh and also from other state offices. Unit of study is tehsil. Two time periods of 1990-91 and 2014-15 are selected. For each time period, three years averages are taken. Statistical techniques are used and cartographic methods are applied for mapping the results.
\end{abstract}

Keywords: Ranking, Regionalization, Cropping Pattern 


\section{Introduction}

Maize or corn is a cereal crop that is grown widely throughout the world in a range of agroecological environments. Maize is the most widely produced crop in the world. This cereal, which originated in Mexico, is now grown in at least 164 countries around the world with a total production of more than 1 billion metric tons in 2013 (Kumar \& Prasher, 2012). Maize is one of most important cereal crops in the world and globally call queen of cereals, because of its highest genetic yield potential among the cereals. It is a stapple food to large chunk of the world population and also an important ingredient in food, feed and a large number of industrial products. It has acquired a dominant role in the agricultural sector and in the macro economy of Asian region. Maize uses as food for humans, feed for poultry and cattle, highquality industrial starches (Mauria and Gupta, 1998).Maize occupies a pride place among coarse cereal crops in India with the rise in standard of living population and to fetch higher prices from maize cultivation, an increase in maize area for its diversified use, like pop corn, sweet corn, baby corn, quality protein maize, etc. is being noticed, particularly in peri urban agriculture (Singh and Choudhary, 2008). Maize occupies an important position in Indian agriculture. Among cereals, it ranks fifth in area and third in production in the country. It can be used at any stage of its growth (Rai, et al., 2005). Maize is used as human food and livestock feed.It is these diverse combinations that made maize so important to the rest of the world as it augmented other crops as a food and livestock feed (Wikipedia). The study of ranking of crops grown in the cropping pattern of a region/ state / country becomes necessary, because it throws light on the significance of individual crops. From ranking, one can understand the position of a crop in the given cropping pattern of a region (Weaver, 1954).In 2014-15 India produces 243 lakh tons from an area of 90.6 lakh hectares, while Himachal Pradesh produces 6.52 lakh tons from 2.9 lakhs hectares. Thus, Himachal Pradesh ranks $11^{\text {th }}$ in area as well as production of maize in India's maize area and production (Agricultural Statistics at a Glance, 2016). The cop ranking is generally done on dominance of area under specific crops. Thus, elements for measuring the ranking of crops are: area under the individual crops and total cropped area (Sohal, 2003). In the present paper, for evaluation of changes in the rank of maize in the cropping pattern crops like rice, wheat, maize, pulses, fruits, vegetables, oilseeds and fodder are taken The cultivation of these crops is the direct impact of climate, soils, physiography, drainage, irrigation, agricultural infrastructure, etc.

\section{Study Area}

Himachal Pradesh is situated in the lap of Himalayan ranges in the North -West of the country. It extends between $30^{\circ} 22^{\prime} 44^{\prime \prime} \mathrm{N}$ latitude to $33^{\circ} 12^{\prime} 40^{\prime \prime} \mathrm{N}$ latitude and $75^{\circ} 40^{\prime} 55^{\prime \prime} \mathrm{E}$ longitudes to $79^{\circ} 04^{\prime} 20^{\prime \prime} \mathrm{E}$ longitudes. It covers $55,673 \mathrm{sq}$. km.area, which is about 1.69 percent of India's total reporting area. The climate of Himachal Pradesh ranges between sub-tropical to temperate. The mean annual temperature of Himachal Pradeshvaries between $-4^{\circ} \mathrm{C}$ in extreme northern parts to $30^{\circ} \mathrm{C}$ in the south-western parts particularly in Una district. While its average annual rainfall varies from $70 \mathrm{cms}$. to $300 \mathrm{cms}$. Total population of the study region is $68,56,509$ persons according to 2011 census. For administrative purpose, there are 85 tehsils which are grouped into 12 districts.

\section{Objectives}

1. To explain spatial patterns of ranking of crops for 1990-91and 2014-15.

2. To find out the changes in ranking order of maize in the cropping pattern during study period.

3. To highlight the factors responsible for changes in ranking of maize crop. 
Fig. 1

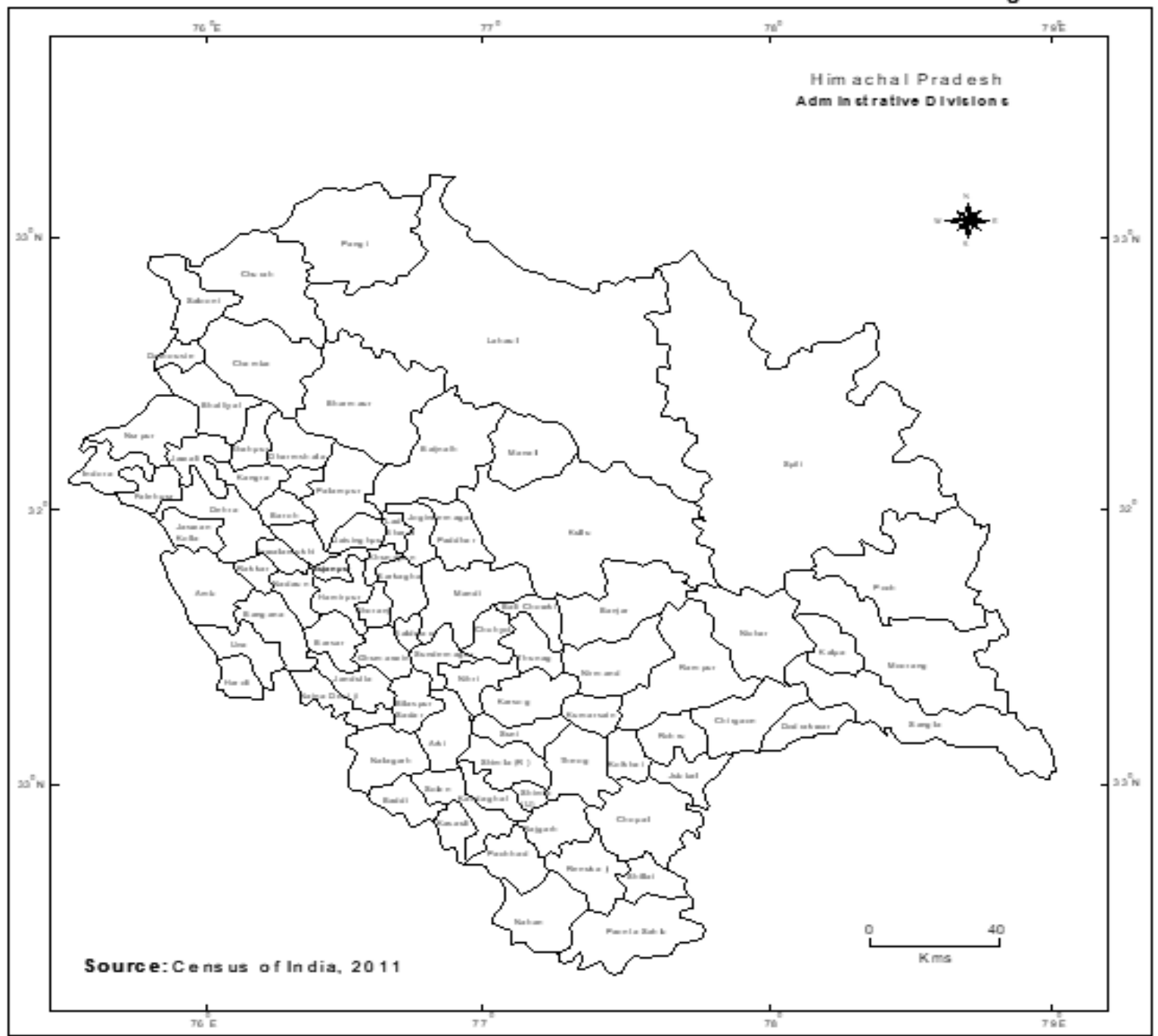

\section{Methodology and Sources of Data}

Secondary sources of data is taken for the present study, which is collected particularly from all tehsil'sheadquarters. Tehsil is selected as unit of study. For each time periodi.e., 1990-91 and 2014-15, three years averages are taken. In the present paper, for the evaluation of changes in the ranking of maize crop in the cropping pattern,crops included are wheat, maize, rice, pulses, fruits, vegetables, oilseeds and fodder crops. For deriving the results, Weaver's (1954) method is used and for presentation the results,simple choropleth technique is applied.

\section{Discussion}

The presentpaper is divided into three parts:-

A.Position of Maize Crop in the Cropping Pattern of Himachal Pradeesh: 1990-91.

B.Positionof MaizeCrop in the Cropping Pattern of Himachal Pradesh: 2014-15.

C.Changes in Position of Maize Crop in the Cropping Pattern of Himachal Pradesh: 1990-91 to 2014-15.

\section{A. Position of Maize Crop in the Cropping Pattern of Himachal Pradesh: 1990-91}

Maize cultivation enjoyed second rank in the overall cropping pattern of Himachal Pradesh in 1990-91, though its rank was not uniformly distributed throughout the study region, because it varied from first rank to seventh rank. First rank covered majority of the tehsils and seventh rank was found in only three tehsils namely Spiti, Dodrakwar and Pooh. Hence, to know reasons responsible for these great variations in ranking order of maize cultivation in different tehsils of the study area in 1990-91, fig. 2 is mapped which depicts five categories: 


\section{Maize as First Rank Crop}

It comprised of thirteen tehsils and covered 15.29 percent of total occurrences. These tehsils were Bilaspur Sadar, Churah, Chamba, Salooni, Dalhousie, Bharmaur, Theog, Rajgarh, Solan, Kasauli, Baddi, Arki and Kandaghat. This category had two belts: first belt lied in north-western parts having tehsils of Chamba, Churah, Salooni, Dalhousie and Bharmaur. Here, reasons for first ranking of maize crop in cropping pattern were presence of hills and mountains, undulating and dissected terrain, high rainfall, poor irrigation facilities, stapple food etc.Thus, farmers preferred maize cultivation, because rice could not be grown successfully in such conditionssupplemented by assured economic returns from maize as compare to rice. While second belt had seven tehsils namely Bilaspur Sadar, Theog, Rajgarh, Solan, Baddi, Kasauli, Kandaghat and Arki. In this belt also, physical as well as socio-economic conditions were favorable for its cultivation as compare to rice, pulses, oilseeds, fruits, vegetables, etc.

Fig. 2

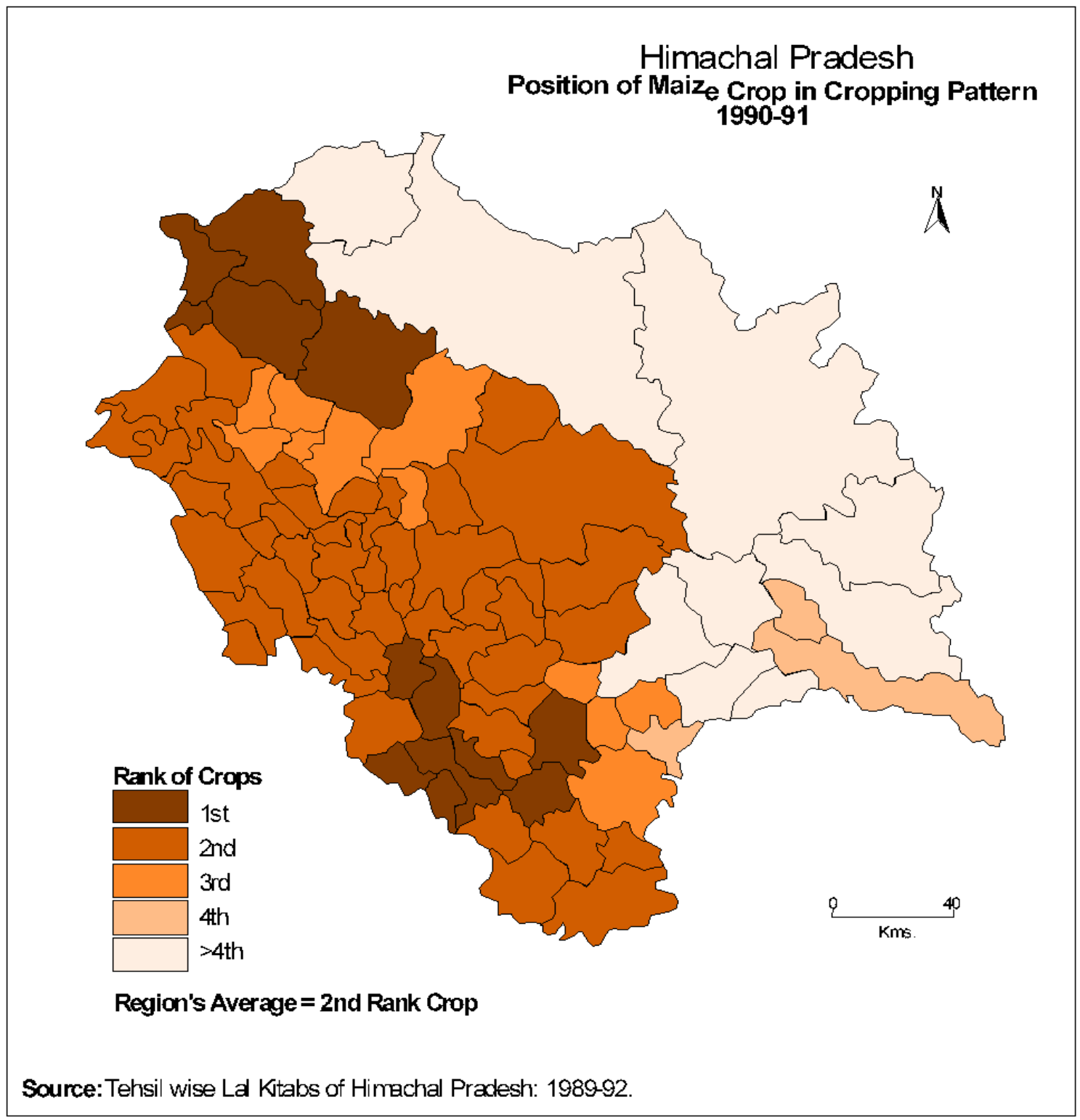


Table 01: Himachal Pradesh, Position of Maize Crop in Cropping Pattern: 1990-91

\begin{tabular}{|c|c|c|c|c|c|}
\hline \# & Tehsils & Percent & \# & Tehsils & Percent \\
\hline 1 & Bilaspur Sadar & 1 & 44 & Spiti & 7 \\
\hline 2 & Jandutta & 2 & 45 & Mandi & 2 \\
\hline 3 & Naina Devi ji & 2 & 46 & Sundernagar & 2 \\
\hline 4 & Ghumarwin & 2 & 47 & Sarkaghat & 2 \\
\hline 5 & Pangi & 7 & 48 & Jogindernagar & 3 \\
\hline 6 & Churah & 1 & 49 & Karsog & 2 \\
\hline 7 & Chamba & 1 & 50 & Chchyot & 2 \\
\hline 8 & Salooni & 1 & 51 & Thunag & 2 \\
\hline 9 & Dalhousie & 1 & 52 & Baldwara & 2 \\
\hline 10 & Bhattiyat & 2 & 53 & Bali Chowki & 2 \\
\hline 11 & Bharmaur & 1 & 54 & Sandhol & 2 \\
\hline 12 & Hamirpur & 2 & 55 & Paddhar & 2 \\
\hline 13 & Bhoranj & 2 & 56 & Nihri & 2 \\
\hline 14 & Barsar & 2 & 57 & Lad Bharol & 2 \\
\hline 15 & Nadaun & 2 & 58 & Rampur & 5 \\
\hline 16 & Sujanpur & 2 & 59 & Kumarsain & 3 \\
\hline 17 & Baijnath & 3 & 60 & Suni & 2 \\
\hline 18 & Palampur & 3 & 61 & Shimla (R) & 2 \\
\hline 19 & Jaisinghpur & 2 & 62 & Shimla (U) & 2 \\
\hline 20 & Dharmshala & 3 & 63 & Theog & 1 \\
\hline 21 & Shahpur & 3 & 64 & Kotkhai & 3 \\
\hline 22 & Nurpur & 2 & 65 & Jubbal & 4 \\
\hline 23 & Indora & 2 & 66 & Rohru & 3 \\
\hline 24 & Jawali & 2 & 67 & Chirgaon & 5 \\
\hline 25 & Fatehpur & 2 & 68 & Dodrakwar & 7 \\
\hline 26 & Dehra & 2 & 69 & Chopal & 3 \\
\hline 27 & Jaswan Kotla & 2 & 70 & Nahan & 2 \\
\hline 28 & Rakkar & 2 & 71 & Paonta Sahib & 2 \\
\hline 29 & Jawalamukhi & 2 & 72 & Pachhad & 2 \\
\hline 30 & Khundyian & 2 & 73 & Rajgarh & 1 \\
\hline 31 & Kangra & 3 & 74 & Shillai & 2 \\
\hline 32 & Nagrota Bagwan & 3 & 75 & Renuka ji & 2 \\
\hline 33 & Baroh & 2 & 76 & Solan & 1 \\
\hline 34 & Kalpa & 4 & 77 & Nalagarh & 2 \\
\hline 35 & Moorang & 5 & 78 & Kasauli & 1 \\
\hline 36 & Pooh & 7 & 79 & Baddi & 1 \\
\hline 37 & Nichar & 6 & 80 & Arki & 1 \\
\hline 38 & Sangla & 4 & 81 & Kandaghat & 1 \\
\hline 39 & Kullu & 2 & 82 & Una & 2 \\
\hline 40 & Manali & 2 & 83 & Amb & 2 \\
\hline 41 & Banjar & 2 & 84 & Bangana & 2 \\
\hline 42 & Nirmand & 2 & 85 & Haroli & 2 \\
\hline 43 & Lahaul & 5 & \multicolumn{3}{|c|}{ Region`s Average : 2 Rank Crop } \\
\hline
\end{tabular}

Source: Tehsil- Wise Lal Kitabs of Himachal Pradesh: 1989 to 1992

\section{Maize as Second Rank Crop}

This category covered 49 tehsils which includes 57.64 percent of total occurrences. These tehsils were Jandutta, Ghumarwin, Naina Devi ji, Bhattiyat, Hamirpur, Bhoranj, Barsar, Nadaun, Sujanpur, Jaisinghpur, Nurpur, Indora, Jawali, Fatehpur, Dehra, Jaswan Kotla, Rakkar, Jawalamukhi, Khundiyan, Baroh, Kullu, Manali, Banjar, Nirmand, Mandi, Sundernagar, Sarkaghat, Karsog, Chchyot, Thunag, Baldwara, Bali-Chowki, Sandhol, Paddhar, Nihri, Lad-Bharol, Shimla (R), Shimla (U), Nahan, Paonta Sahib, Pachhad, Shillai, 
Renuka ji, Nalagarh, Una, Amb, Bangana and Haroli. Here, geo-climatic and socio-economic conditions were favourable for maize cultivation in kharif season, but in rabi season wheat is predominant crop which covered more areas and ranks first in the cropping pattern. Though in all these tehsils, maize was enjoying first rank in kharif season, but in overall cropping pattern its position was second owing to first position of wheat.

\section{Maize as Third Rank Crop}

There were two belts which contained eleven tehsils and 12.94 percent of total occurrences. Tehsils included in this category were namely Baijnath, Palampur, Dharmshala, Shahpur, Kangra, Nagrota Bagwan, Jogindernagar, Kumarsain, Kotkhai, Rohru and Chopal. First belt lied in Kangra district and includes Baijnath, Palampur, Dharmshala, Shahpur, Kangra, Nagrota Bagwan. Here, the third position of maize in cropping pattern was due to presence of Palampur Valley, availability of irrigation water from kuhls, high rainfall during summers, higher and assured economic returns from rice than maize. While second belt covered tehsils of Rohru, Kotkhai, Kumarsain and Chopal. In these tehsils, mountains, temperate climatic conditions, heavy snowfall during winters, steep gradient, etc. created excellent conditions for the cultivation of fruits, wheat, etc. and as a result maize pushed to third position in cropping pattern by these crops.

\section{Maize as Fourth Rank Crop}

Three tehsils namely Kalpa, Sangla and Jubbal formed this category, which contained 3.53 percent of total occurrences. In these tehsils, fruits, vegetables, wheat, barley and millets were predominant crops, because of severe winters, having snowfall, mountainous topography, steep slopes and less developed socio-economic conditions, etc. These were not ideal conditions for maize crop and as a result, it had fourth position.

\section{Maize as Above Fourth Rank Crop}

It was a continuous belt, where position of maize crop varied from fifth to seventh. It had nine tehsils namely Pangi, Moorang, Pooh, Nichar, Lahaul, Spiti, Rampur, Chirgaon andDodrakwar. Here, occurrence of heavy snowfall during winters which started melting after month of April and allow very short growing period of crops like maize, pulses, etc. Thus, owing to severe geo-climatic conditions, farmers preferred wheat, fruits (especially apple orchards) and vegetables as compare to maize. Wheat generally sown before starting of winter season and after melting of snow, wheat started growing when enough heat became available after the month of April. With the melting of snow, it started growing and maturing. Therefore, under such conditions farmers hardly grow maize on gentle slopes for their domestic consumption, which pushed it to negligible share in cropping pattern. Thus, these were the main reasons for insignificant position of maize crop in these parts of Himachal Pradesh.

\section{B. Patterns of Position of Maize Crop in the Cropping Pattern of HP, 2014-15}

Maize is enjoying first position in kharif season but second in overall cropping pattern of Himachal Pradesh during 2014-15. Spatially speaking, all tehsils of the study region do not have second rank in their overall cropping pattern, but varies between first to seventh rank. Thus, to find out reasons responsible for this uneven distribution of ranking order in maize cultivation, an attempt is made with the help of fig. 3 and table no. 2 which display five categories and these are discussed below:

\section{First Rank Crop}

It includes ten tehsils which are found in two belts. First belt has three tehsils of Chamba district namely Chamba, Churah and Salooni. But, second belt contains seven tehsils which are Jandutta, Ghumarwin, Sundernagar, Chchyot, Thunag, Baldwara and Bali-Chowki. These 
areas are hilly and mountainous areaswith steep slopes, absence of irrigation, high rainfall, staple food, etc. and are the main reasons for its first rank, because in such conditions, cultivation of other crops like rice is not possible particularly during kharif season. Moreover, in rabi season, due to snowfall and severe climatic conditions, less area is under rabi crops especially wheat.

\section{Maize as Second Rank Crop}

This is the largest category which confines to western half of Himachal Pradesh with certain interruptions. These tehsils fall in the districts of Chamba, Kangra, Una, Hamirpur, Bilaspur, Solan, Sirmaur, Shimla, Mandi and Kullu. All these areas have hilly, mountainous, undulating and dissected topography, moderate to high rainfall, nearly absence of irrigation, soil shallow in depth which is moderate in fertility, use of maize as food and fodder, etc. All these factors are responsible for second rank in the cropping pattern, though maize enjoys first rank in kharif cropping pattern.

Fig. 3

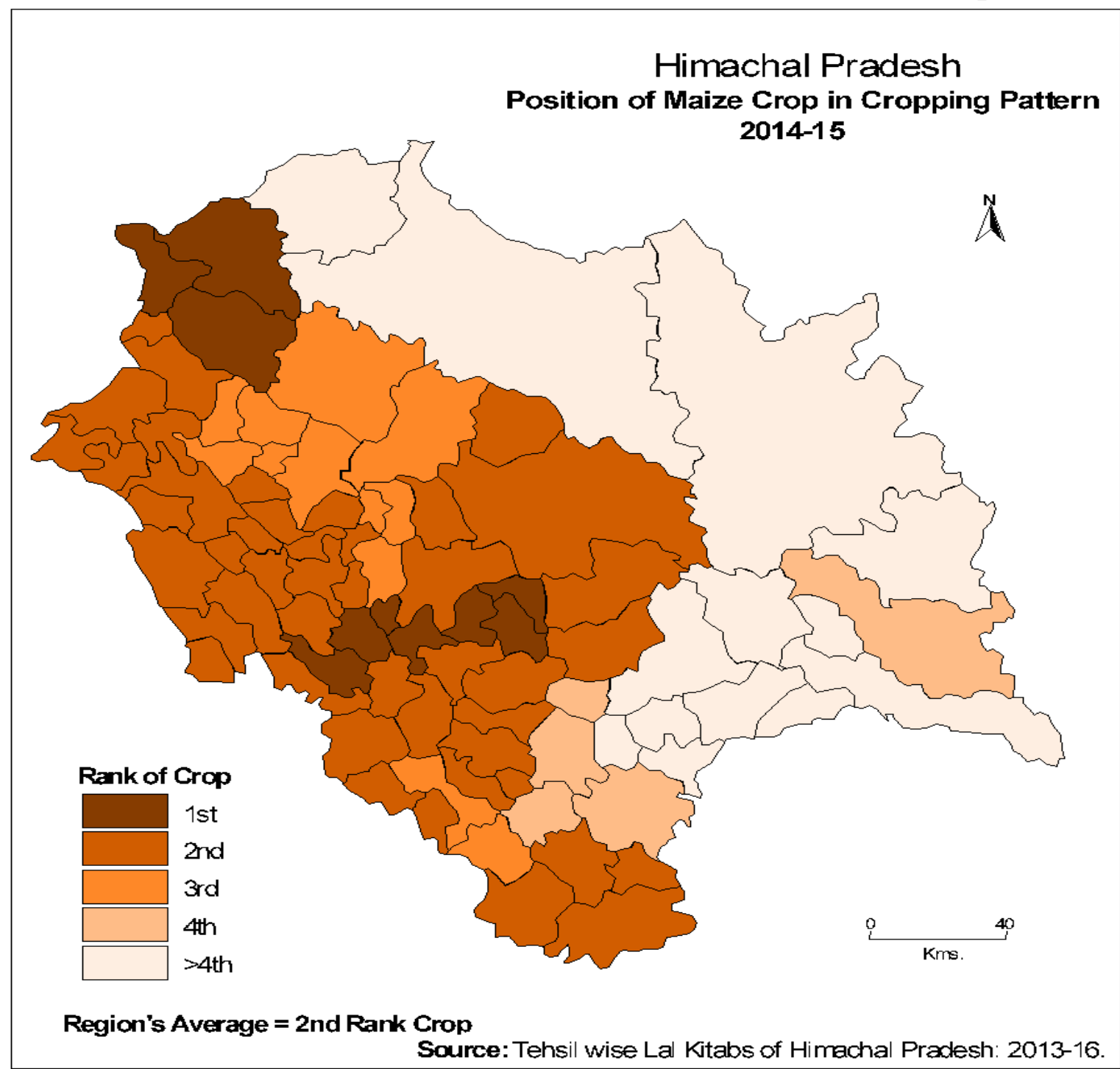


Table 02: Himachal Pradesh, Position of Maize Crop in Cropping Pattern: 2014-15

\begin{tabular}{|c|c|c|c|c|c|}
\hline \# & Tehsils & Ranking order & $\#$ & Tehsils & Ranking order \\
\hline 1 & Bilaspur Sadar & 2 & 44 & Spiti & 7 \\
\hline 2 & Jandutta & 1 & 45 & Mandi & 2 \\
\hline 3 & Naina Devi ji & 2 & 46 & Sundernagar & 1 \\
\hline 4 & Ghumarwin & 1 & 47 & Sarkaghat & 3 \\
\hline 5 & Pangi & 5 & 48 & Jogindernagar & 3 \\
\hline 6 & Churah & 1 & 49 & Karsog & 2 \\
\hline 7 & Chamba & 1 & 50 & Chchyot & 1 \\
\hline 8 & Salooni & 1 & 51 & Thunag & 1 \\
\hline 9 & Dalhousie & 2 & 52 & Baldwara & 1 \\
\hline 10 & Bhattiyat & 2 & 53 & Bali Chowki & 1 \\
\hline 11 & Bharmaur & 3 & 54 & Sandhol & 2 \\
\hline 12 & Hamirpur & 2 & 55 & Paddhar & 2 \\
\hline 13 & Bhoranj & 2 & 56 & Nihri & 2 \\
\hline 14 & Barsar & 2 & 57 & Lad Bharol & 3 \\
\hline 15 & Nadaun & 2 & 58 & Rampur & 5 \\
\hline 16 & Sujanpur & 2 & 59 & Kumarsain & 4 \\
\hline 17 & Baijnath & 3 & 60 & Suni & 2 \\
\hline 18 & Palampur & 3 & 61 & Shimla $(R)$ & 2 \\
\hline 19 & Jaisinghpur & 2 & 62 & Shimla (U) & 2 \\
\hline 20 & Dharmshala & 3 & 63 & Theog & 4 \\
\hline 21 & Shahpur & 3 & 64 & Kotkhai & 5 \\
\hline 22 & Nurpur & 2 & 65 & Jubbal & 7 \\
\hline 23 & Indora & 2 & 66 & Rohru & 6 \\
\hline 24 & Jawali & 2 & 67 & Chirgaon & 6 \\
\hline 25 & Fatehpur & 2 & 68 & Dodrakwar & 5 \\
\hline 26 & Dehra & 2 & 69 & Chopal & 4 \\
\hline 27 & Jaswan Kotla & 2 & 70 & Nahan & 2 \\
\hline 28 & Rakkar & 2 & 71 & Paonta Sahib & 2 \\
\hline 29 & Jawalamukhi & 2 & 72 & Pachhad & 3 \\
\hline 30 & Khundyian & 2 & 73 & Rajgarh & 4 \\
\hline 31 & Kangra & 3 & 74 & Shillai & 2 \\
\hline 32 & Nagrota Bagwan & 3 & 75 & Renuka ji & 2 \\
\hline 33 & Baroh & 2 & 76 & Solan & 3 \\
\hline 34 & Kalpa & 7 & 77 & Nalagarh & 2 \\
\hline 35 & Moorang & 4 & 78 & Kasauli & 2 \\
\hline 36 & Pooh & 6 & 79 & Baddi & 2 \\
\hline 37 & Nichar & 5 & 80 & Arki & 2 \\
\hline 38 & Sangla & 6 & 81 & Kandaghat & 2 \\
\hline 39 & Kullu & 2 & 82 & Una & 2 \\
\hline 40 & Manali & 2 & 83 & Amb & 2 \\
\hline 41 & Banjar & 2 & 84 & Bangana & 2 \\
\hline 42 & Nirmand & 2 & 85 & Haroli & 2 \\
\hline 43 & Lahaul & 8 & \multicolumn{3}{|c|}{ Region`s Average : 2 Rank Crop } \\
\hline
\end{tabular}

Source: Tehsil - Wise Lal Kitabs of Himachal Pradesh: 2013-16.

\section{Maize as Third Rank Crop}

Twelve tehsils namely Bharmaur, Baijnath, Palampur, Dharmshala, Shahpur, Kangra, Nagrota Bagwan, Sarkaghat, Jogindernagar, Lad-Bharol, Pachhad and Solan form this category. Out of twelve tehsils, ten lies in Kangra and Mandi districts. These are valley areas having availability of irrigation from kuhls, fertile soil, comparatively high degree of farm mechanization, etc. which encouraged the farmers to cultivate rice as compare to maize. Hence, this region has maize as a third ranking crop. Here, there are also some valley areas 
with adequate irrigation facilities which push maize to second rank in kharif season and third in the overall cropping pattern.

\section{Maize as Fourth Rank Crop}

It comprises tehsils of Moorang, Kumarsain, Theog, Chopal and Rajgarh. These areas are favourable for wheat, barley, millets, fruits and vegetables, etc. because of severe winters with heavy snowfall, mountainous topography, steep slopes, etc. and are not ideal conditions for growing of maize crop and as a result, its position is fourth. All these factors lead to maize as fourth ranking crop in the overall cropping pattern.

\section{Maize as above Fourth Rank Crop}

This category covers districts of Lahaul \& Spiti, Kinnaur, eastern parts of Shimla and northern parts of Chamba. These areas mostly lie in eastern parts of the study region and contain thirteen tehsils and 15.30 percent of total occurrences. Tehsils falls in this category are Pangi, Lahaul, Spiti, Pooh, Nichar, Kalpa, Sangla, Rampur, Chirgaon, Dodrakwar, Kotkhai, Rohru and Jubbal. Here position of maize varies between fifth to seventh. Main factors which led to above fourth rank of maize are heavy snowfall during winters, short crop growing season, predominance of wheat, fruits, vegetables, barley, millets, etc. It is very interesting to know that in Spiti tehsil, hundred percent area is irrigated with kuhls irrigation, because area under cultivation is very small.To sum up the study has revealed that areas with high rainfall, hilly and mountainous terrain with moderate to steep gradient are having either first or second rank of maize cultivation. While valley areas or areas with gentle gradient and sufficient Kuhl irrigation have recorded third rank. But areas with predominance of fruits, vegetables, wheat, barley and millets followed by heavy snowfall during winters, etc. have recorded least ranks of maize cultivation which range from fourth to seventh. Thus, the rank of maize cultivation in overall cropping pattern reflects its importance in farmer's economy as well as in region's economy.

\section{C.) Changes in Position of Maize Crop: 1990-91 to 2014-15}

During period under investigation Himachal Pradesh has undergone some changes in socioeconomic parameters and improvements in physical environment. For instance, leveling of piedmont plains, reclamation of some valley areas, increase in irrigation facilities, road accessibility, market accessibility, use of chemical fertilizers, etc. which have certainly led to increase or decrease in certain crops in overall cropping pattern and has affected the share of maize crop in the cropping pattern, which further led to changes in ranking order. In some areas, ranking of maize crop has increased and in some other tehsils has decreased. For evaluation the changes in ranking order of maize crop, help is taken from (figure 2 and 3 ) and tables (1 and 2). Thus, the analysis of these figures and tables reveal the following points.

1.There were 13 tehsils with first position in the cropping pattern in 1990-91, but their number decreased to 10 in 2014-15 and resulted into a loss of 3 tehsils which joined the second rank category.

2.The number of tehsils with second position was 49 which come down to 45 during 1990-91 to 2014-15 and experienced a loss of 4 tehsils. It shows that the area under maize crop as well as its position in the cropping pattern of the individual tehsils have declined. A detailed investigation of the share of each crop in the individual cropping pattern of all these tehsils shows that crops like vegetables, fruits and wheat have gained more area under their cultivation which consequently lead to decrease in position of maize in the cropping pattern of these individual tehsils. 
3.While in the case of crops having third position in 1990-91, their number have increased from 11 to 12 and experienced gain of 1 tehsil, which is the result of increased in area under maize in these tehsils owing to development works. Same is the case with $4^{\text {th }}, 5^{\text {th }}$, and $6^{\text {th }}$ rank crops, because these have gained area in two, one and three tehsils respectively. Moreover, it shows that in areas where maize was not significant crop in 1990-91 have captured more area under maize cultivation. Secondly, it is also found that tehsils which have lost their position as second rank had joined the category of either third or fourth or fifth or sixth position.

4.While the number of tehsils of maize with $7^{\text {th }}$ position has come down from 4 to 3 and suffered a loss of 1 tehsil, and has joined the $8^{\text {th }}$ position which is Lahaul tehsil.

5.Overall, it is deduced that 51 tehsils have experienced no change in their position during study period. While 13 tehsils have experienced positive change of one rank. 3 tehsils with first rank have remained their position throughout the study period. While 6 tehsils have joined from $1^{\text {st }}$ to $2^{\text {nd }}$ position and 3 tehsils from $1^{\text {st }}$ to $3^{\text {rd }}$ position. In case of $2^{\text {nd }}$ rank crops, there are 37 tehsils which have not experienced any change in their position. But 3 tehsils with $2^{\text {nd }}$ rank have joined $3^{\text {rd }}$ position and 7 tehsils have improved their position from second to first. But the remaining tehsils either gained or lost their position from 3rd, 4th, 5th and 6th to 4 th, $5^{\text {th }}, 6^{\text {th }}$, $7^{\text {th }}$, etc.

\section{Suggestions}

Himachal Pradesh is ideal state for maize cultivation. Thus, in lieu to increase in area and production, the following suggestions are made:

1. The piedmont area of the state should be levelled and bring under its cultivation.

2. Sprinkle irrigation should be developed so that in lean periods, water requirements of the crop can be met.

3. Farmers should be encouraged to adopt high yielding varieties of seeds by imparting training to them by extension department of State governments and Himachal Pradesh Agricultural University.

4. Research in maize crop should be encouraged to improve the maize seeds.

5. Agro industries based on maize produce should be installed in the study area.

6. The use of agro-chemicals should be encouraged particularly where manure fertilizers are not available.

7. Marketing system should be strengthened and minimum support price of maize be assured to farmers.

If the above-mentioned suggestions are implemented, then area, yield and production of maize will certainly increase which will lead to increase in farmer's income.

\section{Conclusion}

The study has observed that in 1990-91, there were sixty-two tehsils in Himachal Pradesh withfirst and second rank of maize in cropping pattern which indicates its importance in the cropping pattern, because these are areas of high rainfall, rugged, hilly and mountainous topography, etc.But in eleven tehsils, its rank was third due to valley areas and availability of irrigation from kuhls, thus in such condition's farmers preferred rice as major kharif crop and pushed maize to third position. But areas of heavy rainfall, mountainous relief and low to moderate rainfall had first position either as fourth or fifth or sixth or seventh, because in these areas farmer's preferred cultivation of wheat, fruits, vegetables, barley, millets, etc. Moreover, low temperature and short growing season have also created obstacles in maize cultivation.In 2014-15, the study has sum up those areas with high rainfall, hilly and mountainous terrain with moderate to steep gradient, etc. have either first or second rank of maize cultivation in the cropping pattern. While valley areas or areas with gentle gradient and sufficient Kuhl irrigation have recorded third rank. But areas with heavy snowfall during winters and predominance of 
fruits, vegetables, wheat, barley and millets have recorded least rank of maize cultivation which ranges from fifth to seventh. Thus, the rank of maize cultivation in overall cropping pattern reflects its importance in farmer's economy as well as in region's economy.Overall the study has concluded that 26 tehsils have experienced gained in their position and 12 tehsils have lost their position during study period. While no change is noted in 51 tehsils. It is also observed that maize has remained the second rank crop in the overall cropping pattern in the study region during 1990-91 to 2014-15.

\section{References}

1. Agricultural Statics at a Glance- (2016). Himachal Pradesh, pp.35, 37, 42.

2. Agricultural Reports, Department of agriculture. Government of Himachal Pradesh, Himachal Pradesh, India, pp.3, 7, 21-23.

3. Census of India, 2011, Himachal Pradesh, pp.14-15.

4. Kumar, S. and Prasher, D (2012)."An Analysis on Changing Trends of Food Grains in Himachal Pradesh",International Journal of Pharmacy life science, Vol.6, pp.1739-1742.

5. Mauria, S. and Gupta, N.P. (1998). "Maize Research in India - Progress and Future Challenges", Indian Farming, Vol. 48, No. 1, pp. 110-112.

6. Rai,et.al.(2005). "Cultivation of Sweet Corn", Indian Farming, Vol. 54, No.10, pp. 10-12.

7. Singh, D. and Chaudhary,(2008),"Effect of Plant Population and Fertilizer levels on Yield and Economics of Pop Corn", Indian Journal of Agricultural Sciences, Vol.78, No.4, pp.370-371.

8. Sohal, K.S.(2003). "Changes in Crop Diversification in Punjab:1951 - 2001", National Geographical Journal of India, Vol. 49, pp. 33-42.

9. Statistical abstract of Himachal Pradesh: 2016, pp.50-52.

10. Tehsil Wise Lal Kitabs of Himachal Pradesh: 1989 to 1992 and 2013-16.

11. Weaver, J.C. (1954). "Crop Combination Regions in Middle-West" Geographical Review, Vol. 44, pp.180-187.

12. www.wikipedia.com 